\title{
Experimental analysis of reinforced concrete block masonry beams using pre-fabricated planar trussed bars
}

\author{
Vladimir G. Haach ${ }^{1}$ \\ Graça Vasconcelos ${ }^{2}$ \\ Paulo B. Lourenço ${ }^{3}$
}

\begin{abstract}
Masonry beams together with shear walls integrate the resistant system of a masonry building responsible to bear the lateral loads. Shear walls are the main components in this structural system, even if masonry beams are the elements that ensure the connection of panels and the distribution of stresses through the masonry piers. In addition, the use of prefabricated truss type bars for transversal and longitudinal directions is considered to be a challenge. The use of these bars can increase the productivity in construction of reinforced masonry buildings due to the facility of application. Therefore, this paper focus on the experimental of masonry beams reinforced with pre-fabricated planar trussed bars. Different possibilities for the construction of lintels with concrete masonry beams have been tested. Reinforced concrete beams with three and two hollow cell concrete blocks and with different reinforcement ratios have been built and tested in a four and three point loading test configuration. It was clear that horizontal bed joint reinforcement increased the capacity of deformation as well as the ultimate load, leading to much more ductile responses.
\end{abstract}

1 - PhD Student, ISISE, Department of Civil Engineering, University of Minho, Azurém, 4800-058 Guimarães, PORTUGAL, Phone: (+351) - 253510200, Fax: ( 351) - 253510217, E-mail: vghaach@pop.com.br

2 - Assistant Professor, ISISE, Department of Civil Engineering, University of Minho, Azurém, 4800058 Guimarães, PORTUGAL, E-mail: graca@civil.uminho.pt 3 - Professor, ISISE, Department of Civil Engineering, University of Minho, Azurém, 4800-058 Guimarães, PORTUGAL, E-mail: pbl@,civil.uminho.pt 


\section{Introduction}

In masonry buildings the masonry beams are the structural elements responsible for the distribution of vertical loads over openings, see Fig. 1. Combined with shear walls, masonry beams play a major role on the distribution of lateral actions in masonry buildings providing the coupling of masonry piers. They may be built by using other materials such as steel profiles and precast reinforced concrete elements. However, in these cases, special care should be taken to consider the composite behaviour of masonry and the other material.

According to Drysdale et al. (1999) the design of multi-storey buildings considering simple cantilever shear walls assures ductile response and good energy dissipation when they are properly designed and built. The consideration of perforated or of coupled masonry shear walls renders its design rather complex. Plastic hinging in the masonry beams is assumed in the behavior of coupled shear walls, meaning that some plastic deformation capacity and, thus, ductility is required for this type of structural element. However, due to the low span to depth ratio of coupling beams, it is difficult to satisfy the demand of ductility. Therefore, Drysdale et al. (1999) suggest the separation of the beams from adjacent walls by movement joints, even if this procedure is rather severe and underestimates the lateral resistance of the masonry shear walls. The consideration of the coupling beams results in lower flexural efforts at the base of the building than in the case of single cantilever walls are considered.

Masonry beams are subjected to shear and flexure efforts and according to several authors, the design of masonry beams can be performed using the ultimate strength design method similar to what is used in reinforced concrete beams (Khalaf et al., 1983; Hendry, 1998; Drysdale et. al., 1999; Taly, 2001). Nevertheless, the anisotropy of 
masonry, mainly due to mortar joints, which act as planes of weakness, become the behaviour of masonry beams more complex.

There has been very few works analyzing the behaviour of masonry beams until now. Khalaf et al. (1983) tested a total of eight fully grouted concrete block masonry beams divided in two series: a series with span to depth ratio of about 9 and another series with span to depth ratio of about 6 . In both series variable levels of tensile reinforcement were considered aiming at assessing its influence on the load-deflection behaviour and on the strength in flexure. Authors confirmed the assumption that plane sections remain plane during bending and o provide an ultimate compressive strain for masonry of about 0.003 .

Limón et al. (2000) tested ten brick masonry beams (span to depth ratio equal to 4.5) reinforced with truss type prefabricated bars through four point load configuration aiming at analysing the flexural behaviour of masonry. Variables like the depth of the neutral axis, the quantity of reinforcement, the overlap of wires and the shear behaviour of masonry were considered in the analysis. Specimens exhibited an ultimate load up to $100 \%$ higher than the predicted values based on flexural strength design method. Authors assumed that the high experimental resistance was attributed to the lower reinforcement area considered in the calculations as the diagonal bars were not taken into account. Considering also the area of diagonal bars Limón et al. (2000) obtained experimental resistances in some specimens close to theoretical values. Other authors studied also the influence of the distribution of tensile reinforcement on the flexural strength of masonry beams. According to Jang and Hart (1995) and Adell et al. (2008), the uniform distribution of reinforcement has advantages over concentrated reinforcements both at top and bottom layers, improving the shear resistance by dowel 
action, even if displacement ductility decreases.A particular issue related to the behavior of masonry beams under flexure is the mobilization of the compressive strength of masonry in the direction parallel to the bed joints. Chen et al. (2008) performed a parametric study on reinforced masonry sections under flexure and observed that compressive strength of masonry has a large influence on the resisting moment in comparison with tensile strength of masonry, which presents only a marginal effect. The main goal of this paper is to present recent experimental research carried out on concrete block reinforced masonry beams aiming at increasing the insight on the mechanical behavior of this type of structural elementunder shear and flexure, given the reduced information available in the literature. Therefore, a large experimental program based on shear and flexure tests was designed, in which three and four point load configurations were adopted. The simplicity on the arrangement of the test setups and on the interpretation of results represents important advantages. The variables under study were the shape of the concrete block masonry units, distribution of tensile strength and distribution of vertical shear reinforcements. Truss type reinforcements were considered both for the tensile and shear reinforcements.

\section{Experimental Program}

The experimental program was carried out at Laboratory of Structures of University of Minho (LEST) aiming at evaluating the mechanical behavior under flexure and shear of reinforced masonry beams through a three and four point load bending test configuration. Twenty four masonry beams were built with different geometry of units and distinct horizontal and vertical reinforcement distribution. 


\section{Test Specimens}

Masonry beams were built with three and two hollow cell concrete blocks (3Cunits and 2C-units, respectively), 4 courses in height, leading roughly to a height of $0.41 \mathrm{~m}$ and 7 or 4 blocks in length, resulting in a span of $1.42 \mathrm{~m}$ and $0.81 \mathrm{~m}$ respectively, see Fig. 2 These distinct geometries aimed to obtain predominant flexural (span to depth ratio of 3.5) and shear responses (span to depth ratio of 2.0) so that flexural and shear mechanical behavior of masonry beams could be analyzed.

Masonry beams were built with distinct masonry bonds, namely dry vertical joints when 3C-units were used and common mortar filled vertical joints with $8 \mathrm{~mm}$ thickness in case of $2 \mathrm{C}$-units. A summary of the typologies of the masonry beams is indicated in Table 1. Fourteen specimens were tested to evaluate the flexural behavior (denoted with letter F) and ten specimens were built to evaluate the shear behavior of masonry beams (denoted with $\mathrm{S}$ ). As aforementioned, 2C and 3C relates the typology of unit, D5 and D3 denotes the diameter of bed joint reinforcement ( $\left.\phi_{h}\right)$, corresponding to distinct reinforcement ratios, $\left(\rho_{h}\right)$, and UM means unreinforced masonry. In the four point bending configuration, in order to avoid shear failure at the supports, two vertical reinforcements of $5 \mathrm{~mm}$ of diameter were introduced in the vertical cores of the concrete blocks between the supports and the load application points, see Fig. 3 and Table 1. Two vertical reinforcements were added at mid-span (specimens indicated with $\mathrm{M}$ ) in order to assess its contribution for the flexural strength and for preventing possible vertical splitting stresses developed at the compressed region due to high concentration of compressive stresses developed in the parallel direction the bed joints. The letters $\mathrm{C}$ and $\mathrm{D}$ are associated to the distinct distribution of tensile reinforcements. The letter $\mathrm{C}$ 
indicates that the reinforcement was only added at the first course, and D indicates that reinforcement was distributed along the depth of the beams.

. In case of shear specimens SH indicates that the masonry beam has only bed joint reinforcements and S1, S2 and S3 indicates different vertical reinforcement ratios, having all vertical reinforcements a diameter of $4 \mathrm{~mm}$. In order to avoid failure by flexure, traditional steel bars $\left(\rho_{h}=0.70 \%\right)$ were placed in a layer of mortar at the base of the beam and truss type reinforcements were added at all bed joints. The distribution of vertical shear reinforcements is shown in Fig.4. It should be mentioned that the position of the vertical reinforcements was to great extent defined by the geometry of the concrete units, mainly as concerns the vertical perforation.

Besides the typology of the masonry units, the ratio and distribution of tensile and shear reinforcements are the main parameters under analysis.

\section{Test setup, instrumentation and procedure}

The static monotonic tests of the masonry beams were performed following two typical load configurations (three and four point bending tests) recommended by EN846-9 (2000), as shown in Fig. 5a) and b).

Masonry panels were laid on the top of two steel roller supports with a cross section of $100 \mathrm{~mm} \times 100 \mathrm{~mm}$ in order to avoid stress concentration, see Fig. 5c. One of the supports was fixed to a steel profile anchored to the reaction slab. The other support was placed above a roller positioned in the direction of the beam to avoid possible torsional deformation. Two Teflon sheets with a layer of grease in between were placed below the steel rollers allowing free motion and avoiding possible axial stresses in masonry beam due to friction effects. 
The vertical load was applied by means of a vertical actuator connected to a load cell and to a spherical hinge and distributed by means of a steel beam in the case of four point load configuration. Half-rollers were placed at the load application points to avoid horizontal friction forces The monotonic tests were carried out under displacement control at a rate of $5 \mu \mathrm{m} / \mathrm{s}$ by means an external LVDT connected to the vertical actuator.

The displacements of the masonry beams were measured by means of a set of LVDTs, according to the localization indicated in Fig. 6. LVDTs 1, 2 and 3 measured the deflections of the beams, whereas LVDTs 4, 5 and 6 intended to measure the slippage of the horizontal joints. The possible opening of vertical flexural crack at midspan was detected by LVDT7. Besides, strain-gauges were glued to reinforcements so that assessment of their contribution to the response of the beams could be possible. In four point load bending tests strain-gauges were glued to the horizontal reinforcements at the mid-span of the beam according to the configuration shown in Fig. 6 a to measure the maximum tensile elongations. In shear specimens strain gauges were glued to horizontal reinforcements in the first course and at the mid height of the vertical reinforcements, see Fig. 6b. Due to the limitation of the acquisition channels, in specimens with vertical reinforcements in the central region of the beam, it was decided not to apply strain gauges in the horizontal reinforcements at the second course.

\section{Material Properties}

The mechanical properties of the materials, namely units, mortar, reinforcement and masonry as a composite material, were obtained through a set of experimental tests. The normalized compressive strength of three and two cell concrete blocks (3C-and 2C-units) was obtained according to EN772-1 (2000) being the average value of 12.1 
$\mathrm{MPa}$ and of 9.4 MPa, respectively. The Young's modulus of the concrete blocks was derived from the compressive stress-strain diagrams, being the average value of 9.6 GPa and $8.8 \mathrm{GPa}$ for $3 \mathrm{C}$ - and $2 \mathrm{C}$-units respectively. The same mortar was applied for the filling of reinforced internal cores and for the laying of masonry units, following a previous study to define a mortar mix with an adequate consistence to use as embedding and as infill material (Haach et al., 2007). As in case of the production of units, special care was also taken with granulometry of the sand used in mortar mix in order to ensure a proper relation between the maximum diameter of the aggregates and the thickness of joints. A general purpose mortar was adopted composed by cement and fine sand in proportion 1:3 (cement/sand) in volume with water/cement ratio equal to 0.90 , corresponding to an average flow table diameter of $180 \mathrm{~mm}$, measured according to EN1015-3 (1999). During the construction of the beams, three specimens of mortar (40 $\mathrm{mm} \times 40 \mathrm{~mm} \times 160 \mathrm{~mm}$ ) were cast aiming at controlling the quality of the material through the compressive, $f_{m}$, and flexural strength, $f_{f}$, obtained according to EN1015-11 (1999). The mortar specimens were tested at the same age of the beams.

The characterization of masonry as a composite material was carried out by means of uniaxial compressive tests and diagonal tests following EN1052-1 (1999) and ASTM E519-02 (2000), respectively. Average values of 5.95 MPa and 5.45MPa were obtained for the compressive strength of $3 \mathrm{C}$ - and $2 \mathrm{C}$-units respectively. The same average value of 10.5 GPa was obtained for the Young's modulus in masonry wallets built with 3Cand $2 \mathrm{C}$-units. It is noted that minor differences were found in the compressive strength of wallets with and without filled central internal cells, according to a previous experimental study (Haach et al., 2008). 
Average values of shear strength of $0.19 \mathrm{MPa}$ and $0.59 \mathrm{MPa}$ were obtained from diagonal tests for masonry wallets built with 3C-and 2C-units respectively. Besides, average values of shear modulus of $1.85 \mathrm{GPa}$ and $2.22 \mathrm{GPa}$ were obtained from diagonal tests for masonry wallets built with $3 \mathrm{C}$ - and $2 \mathrm{C}$-units respectively. These results indicated that masonry with filled vertical joints (built with $2 \mathrm{C}$ units) presents considerable higher shear strength and stiffness. More details on this experimental study can be found in Haach et al. (2010a). In case of reinforcement, three samples were submitted to direct tensile tests, being the average value of the yield stress of $700 \mathrm{MPa}$ and the Young's modulus of $196 \mathrm{GPa}$.

\section{Analysis of Results}

The analysis of mechanical behavior obtained in experimental tests on masonry beams is based on the failure modes observed and on the force-displacement diagrams. Additionally, information of the flexure and shear cracking loads is also provided. In spite of the care taken with the free support to avoid axial stresses in masonry beam, the results obtained point out that the free support exhibited non-negligible stiffness during the tests. However, experimental tests carried out in masonry beams provided some indicators about their flexure and shear behaviour.

\section{Failure modes}

Four point load configuration

In four point load bending tests the central region of the beam is under pure flexure without influence of shear stresses. As the vertical load increases, tensile stresses at the bottom region of the masonry beams increases leading to the attainment 
of the flexural strength of masonry, resulting in the opening of flexural cracks at the vertical joints in the central region of the beam. The opening of this crack could be detected through the results of LVDT 7, which was located at the bottom of the beams. Results showed that flexural crack closed during the post-peak regime in specimens that failed by shear, whereas in specimens failing by flexure this crack remained opened until the end of the test. The summary of the crack patterns obtained in the specimens tested under four point load configuration is shown in Fig7. By comparing the failure pattern among the distinct beams it can be observed that it is dependent on the percentage of horizontal reinforcement placed in the beams, in spite of all beams have vertical reinforcement near at the supports to avoid shear failure. In fact, the masonry beams with horizontal reinforcement with longitudinal bars of $5 \mathrm{~mm}$ diameters failed in shear (F-3C-D5-D, F-3C-D5-D-M, F-2C-D5-D and F-2C-D5-D-M) or in a mixed flexural-shear mode(F-3C-D5-C and F-2C-D5-C), whereas the beams with longitudinal reinforcement of $3 \mathrm{~mm}$ diameters failed predominantly by flexure (F-3C-UM, F-2C-UM, F-3C-D3-C, F-2C-D3-C, F-3C-D3-D, F-3C-D3-D-M, F-2C-D3-D and F-2C-D3-D-M). In case of unreinforced masonry (F-2C-UM and F-3C-UM), the flexural crack pattern is characterized by a stepped crack along the height of the beam resulting from the sudden propagation of the vertical crack developed at the bottom central region of the beam. The flexural cracking patterns follows almost exclusively the unit-mortar interfaces due to their low resistance, when compared to the tensile strength of the concrete units. It should be stressed that, as expected, the presence of horizontal reinforcement enhances the flexural behavior of masonry beams. After the opening of the vertical joints in the first course, bed joint reinforcement prevents the propagation of the flexural cracks along the height of the masonry beam, there having a redistribution of stresses 
between the masonry and bed joint reinforcement. This results in the considerable increase of the shear strength of the mortar-unit interfaces and also in the increase of the compressive stresses at the top of the beam. The yielding of these reinforcements is particularly visible in specimens where only a horizontal reinforcement of $3 \mathrm{~mm}$ diameter is placed at the first course (F-3C-D3-C and F-2C-D3-C). It is observed that horizontal bars exhibited a decrease on strains near failure of the beam, see Fig. 8, which can be attributed to the unloading of the steel bars after its breakage. The straingauges of specimen F-2C-D3-C were probably damaged since the strains measured were very low, in spite of the effective breaking of the bars.

Specimens with horizontal reinforcements, , distributed along the height of the beams (F-3C-D3-D, F-3C-D3-D-M, F-2C-D3-D and F-2C-D3-D-M) exhibited also typical flexural cracking with similar cracking pattern. Apart from specimen F-3C-D3D-M, whose horizontal reinforcement broke at first and second courses, all of the abovementioned specimens exhibited breakage of horizontal reinforcements only at the first course. It is observed that in general the horizontal reinforcements placed at first and second courses present tensile strains, whereas the reinforcement of the third course exhibit compressive strains, as expected. The introduction of vertical reinforcements at mid-span of the beams increased their flexural strength due to the filling of the central internal cores with mortar, resulting in a reduction of strains in reinforcements of the first course.

As abovementioned, the specimens with bed joint reinforcement with longitudinal bars of 5mm diameter placed at the first course (F-3C-D5-C and F-2C-D5C), failed in shear with the development of diagonal cracking between the application point load and the support, even in the presence of vertical reinforcements near the 
support. The shear cracking pattern develops together with the flexural vertical cracks opened at the bottom vertical joint of the central region of the beam. In case of masonry beams built with $3 \mathrm{C}$ concrete blocks, the level of tensile strains developed in the reinforcements at the first course shows that they reach yielding strength which confirms its mixed failure mode.

Specimens with 5mm horizontal reinforcements distributed in all mortar layers failed clearly by shear with the opening of a main diagonal crack between the support and the load application point. The strains measured in the horizontal reinforcements distributed along the height of the specimen indicates that, as expected, the reinforcement at the first course exhibit the maximum tensile strains for all the specimens. The opening of the diagonal crack could be clearly observed through the LVDT 6 positioned near the support measuring the relative displacement between the third and second courses, see Fig. 9. It is clear that the higher horizontal sliding occurs in specimens where diagonal cracking occurs. In case of specimen F-3C-D5-D-M the low level of sliding is related to localization of the diagonal crack in the opposite side, which was not instrumented. The decreasing of the strains after the maximum load was reached indicates that total capacity of horizontal reinforcements were not used, confirming the shear failure of the masonry beams, see Fig. 10.

The geometry of the concrete block masonry units presents some influence on the mechanical behavior of masonry beams. The tensile strains developed in the reinforcements of beams built with the $3 \mathrm{C}$-units present almost always higher values than the tensile strains of reinforcements in beams built with $2 \mathrm{C}$-units, meaning that the 3C-units lead to higher ductility. On the other hand, in beams with 3C-units the reinforcement positioned at the third course is clearly in compression, whereas in beams 
with $2 \mathrm{C}$-units the strains are almost zero, meaning that the neutral axis should be at the third course

The addition of the central vertical reinforcements seems to improve the resistance of the beam with $3 \mathrm{C}$-units, even if no significant changes occur in the maximum tensile strain, which means that in relative terms the reinforcement present lower strains, as observed in specimens F-3C-D3-D-M and F-2C-D3-D-M. This is also true in specimens built with $2 \mathrm{C}$-units, which exhibit also a slight reduction on the resistance.

The presence of reinforcements distributed along the height of the specimens represents an increase on the resistance of the beam, resulting in higher resisting moments and, thus, to higher stresses at the upper compressive zone of the beam. These high compressive stresses induce the formation of splitting vertical cracks in the webs of the concrete units. This type of cracking was already detected in the compressive tests carried out on masonry wallets in the direction parallel to bed joints (Haach et al, 2010b). Note that the compressive stresses in the upper region of the beam develop in the direction parallel to the bed joints. The high compression in upper region of the beam led also to the splitting of the third course due to the low tensile strength of the unit-mortar interface. This behaviour is particularly evident when flexural response is predominant, which is associated to high compressive stresses developed in upper region of the beam. The separation of concrete units was also visible in compressive tests in parallel direction to the bed joints carried out on masonry wallets (Haach et al., 2010b). The use of vertical reinforcements at the mid-span of the panels resulted in a good control of cracking. It avoids or at least, reduces tensile cracking at the unit-mortar interface, see Fig. 7. These bars exhibit higher strains in specimens built with 3C-units 
as the masonry presents lower compressive strength parallel to bed joints and higher ductility, see Fig. 11. On the other hand, it is clear that the strains are higher in reinforcements with $3 \mathrm{~mm}$ longitudinal diameter, which is associated to the predominant flexural cracking, conversely to the specimens with $5 \mathrm{~mm}$ longitudinal diameter that presents a mixed flexural-shear or shear failure.

Three point load configuration

Apart from specimen S-2C-SH, all masonry beams tested under three point load configuration presented a shear failure mode. Specimen S-2C-SH, which was the first to be tested, presented crushing of the unit under the load application point due to stress concentration resulting from the low length of the steel plate placed under the vertical actuator. Higher length of the steel plate, and thus more compatible local compressive stress with strength of the concrete units, was used in the following tests avoiding such local cracking pattern. However, the crushing seemed to occur near the real capacity of the beam since diagonal cracks have been already developed.

It should be stressed that due to the geometry of the specimens and to the horizontal ordinary steel bars placed at the base of the beam no flexural cracking developed. In this test configuration the load path through the beam is composed by two compressed struts connecting the load application point and the supports. The cracking pattern composed by diagonal cracking is a consequence of the stress distribution along the compressed struts. Fig. 12 shows the crack patterns of all specimens tested through the three point loading configuration.

It is clear that both vertical and horizontal reinforcements had influence on the features of the shear crack patterns. For both types of concrete units, the shear crack developed in unreinforced masonry beams is mainly localized along the vertical and 
horizontal unit-mortar interfaces. When horizontal reinforcements are placed at the bed joints, the shear crack is more distributed and develops mainly through concrete units. The horizontal reinforcements lead to the increase on the shear strength of the masonry joints and thus to the increase on shear stresses resulting in cracking of the concreteunits. The horizontal reinforcements provide a better distribution of shear stresses reducing the masonry anisotropy, leading to a much more homogeneous material. Besides, the horizontal reinforcements improve the shear response of the masonry beams by avoiding the brittle failure due to the dowel action. This effect is particularly visible in specimen S-2C-S2, where the localized shear crack is able to attain a considerable large opening, see Fig. 13a. In case of reinforced specimens the higher vertical load applied to the beam results on the increase of compressive stresses on the struts and consequently on the compressive stresses at the upper region of the beams in the parallel direction to the bed joints, resulting in the complete splitting of the concrete units of the third course, see Fig. 13b.

After the opening of the diagonal crack, significant strains are measured in vertical reinforcements as they connect the two edges of the crack and sustain the shear stresses, see Fig. 14. The presence of vertical reinforcements reduced the horizontal undonding and consequent slippage in mortar joints due to the dowel action effect.

It should be stressed that the location of vertical bars has an important influence on their contribution to the resisting mechanism to shear stresses. Reinforcements located out of the diagonal shear band exhibit very low strains, whereas as abovementioned the vertical reinforcements crossing the diagonal crack present increasing strains after diagonal cracking. An exception should be pointed out to the specimen S-2C-S3, where the negligible strains measured are related to the opening of 
the diagonal crack at the opposite side, which is not instrumented with strain gauges. Besides, the distribution of stirrups seemed to have a remarkable influence on the shear crack pattern. This is clear if a comparison between the shear crack bands is made between specimen S-2C-S1 and specimen S-2C-S2. Note that in specimen S-2C-S2, two steel truss type bars bound the localized shear crack, meaning that the contribution for the crack distribution is negligible, leading to the failure for a lower external load than the one obtained in specimen S-2C-S1. On the other hand, the vertical reinforcement placed in specimen S-2C-S1 seems to be effective on the crack distribution as it crosses the diagonal shear band. It should be stressed that a more distributed cracking is achieved by decreasing the spacing of vertical reinforcements, which is the case of specimens S-2C-S3 and S-3C-S3.

Similarly to what happened in the four bending tests, the high compressive stresses in upper region of beams generated cracks in webs of the blocks as observed in characterization tests of masonry wallets tested under compression parallel to bed joints. Besides, the sliding of horizontal blocks over the horizontal joints in the extremities of beams also occurred due to the high shear stresses along mortar joint.

\section{Analysis of the force-displacement diagrams}

Four point load configuration

Fig. 15 shows a summary of the force-displacement diagrams of all specimens tested for four point load configuration. In general, three phases characterizes the forcedisplacement diagrams of masonry beams. There is an initial elastic behaviour corresponding to a high initial stiffness with very small vertical deflections. The second stage is characterized by the opening of flexural cracks at the unit-mortar interface 
located at mid-span, which is associated to an abrupt decrease on the stiffness and to an progressive increase in the load up to the achievement of the maximum strength of the beam. The decrease on the stiffness is particularly evident on specimens behaving in flexure. Thediagonal cracking is only identified by the relative displacements measured at the unit-mortar interface near the supports (LVDTs 4, 5 and 6). The stiffness at the second stage depends clearly on the horizontal reinforcement ratio and on the presence of vertical reinforcements at the mid-span, being increasing for increasing horizontal reinforcement ratio and with the placement of vertical reinforcement at mid-span. After flexural cracking, load transfer from the masonry to the horizontal reinforcements occurs, being the resisting mechanism composed by the tensile strength of the reinforcements and compressive strength of masonry.

The third stage is only visible in the masonry beams failing in shear and is characterized by the softening behavior associated to the reduction on the shear resistance with increasing displacements.

The collapse of masonry beams can occur by yielding of reinforcement, crushing of the masonry in the upper or bottom compressed part or by diagonal cracking. Table 2 shows the cracking and maximum loads found in the four point loads tests. Unreinforced masonry beams present the lowest flexural strength and very brittle behaviour. Besides, slight higher strength was obtained in beams built with $2 \mathrm{C}$-units (filled vertical joints). After flexural cracking at the bottom course, a sudden stair stepped crack follows up to the compressed edge of the beams leading to the abrupt failure. It is observed that the introduction of horizontal reinforcement, the increase on its ratio and its distribution along height assumes a central role on the increase of the strength and ductility of the masonry beams. Considerable higher resistance of 
reinforced beams at bed joints was obtained in comparison with unreinforced masonry beams. Besides, it is clear that horizontal reinforcement ratio and decreasing on the spacing improves the strength of beams.

Specimens predominantly governed by flexure presents considerable higher ductility than the specimens where diagonal shear cracking takes the central role on the behaviour of the beams, with higher deflection corresponding to the maximum resistance and considerable higher ultimate deflection. It is clear that the strength of masonry beams failing in shear is considerable higher when $2 \mathrm{C}$-units are used in the construction of the beams, which appears to be related to the higher shear resistance of masonry with filled vertical joints (Haach et al., 2010a).

Results showed that vertical reinforcements placed at mid-span increased the force corresponding to the flexural cracking, which is associated to the mortar filling of the vertical internal cores of the $3 \mathrm{C}$-units, resulting on the increase of the tensile strength of vertical unit-mortar interface in first course at mid span of the beam. However, by analysing the diagonal crack force, the presence of vertical reinforcements at mid span appears to antecipate the diagonal cracking of the beams, which can be associated to the increasing level of compressive stresses at upper region of beams leading to an increase of compressive stresses on diagonal struts between the load application point and supports.

Three point load configuration

As expected, shear resisting mechanisms prevails in specimens tested under three point load configuration, being the failure mode governed by diagonal cracking. The shear behavior can also be divided in three phases. The linear elastic behavior before diagonal cracking after which non-linear deformations develop up to the maximum 
shear strength. After the peak load is reached the softening behavior is progressively decreasing as the deformation increases, see Fig. 16.

Masonry beams exhibit high initial stiffness, being the maximum load attained for very low deflection of the beams. No significant differences were detected in the shear resistance for both unreinforced masonry beams (with 3C-units and 2C-units).. It is clear that the presence of reinforcements improved the shear behaviour of beams, increased the strength and deformation capacity, and, as observed in four point load tests, delayed the diagonal cracking, see Table 3. Horizontal reinforcements influence positively the shear behaviour by enhancing the crack distribution, as mentioned previously, and by increasing the strength of the beams. Note that the presence of horizontal reinforcements seems also to lead to an improvement of the ultimate deformation capacity for beams with 3C-units, in spite of this is no evident in case of beams built with $2 \mathrm{C}$-units due to the local crushing failure (S-2C-SH). The increase on the global strength results from the improvement of the shear strength of the bed joints as well as from the dowel action effect, which allow additional load transfer between the edges of the shear crack. This effect has been already mentioned for vertical reinforcements in masonry walls subjected to lateral loading (Haach et al., 2010c). Besides the horizontal reinforcements, vertical reinforcements also contribute for global shear strength by connecting both edges of the shear crack through the development of tensile stresses. An increase on the shear strength of the beams with 3C-units of about $18.7 \%, 27.9 \%$ and of $17 \%$ in specimens S-3C-S1, S-3C-S2 and S-3C-S3 was obtained in relation to the specimen with horizontal reinforcement, see Table 3.. For beams built with 2 -units increases of $27.2 \%, 2.4 \%$ and of $88.3 \%$ were observed in specimens S2C-S1, S-2C-S2 and S-2C-S3 in relation to the specimen reinforced in bed joints. Note 
that the vertical reinforcements in specimen S-2C-S2 are out of the diagonal cracking, appearing that only a slight increase on the strength was obtained.

It should be noticed that apart from specimen S-2C-S2, in the other two beams built with $2 \mathrm{C}$-units the increase on the shear strength due to the addition of vertical reinforcements is considerably higher than in specimens built with $3 \mathrm{C}$-units. In case of beams with 3C-units, the vertical reinforcements are placed in the internal cell of the concrete units and at the frogged ends, where mortar with appropriate plasticity was applied in order to obtain the adequate bond between reinforcements and masonry. In case of beams with $2 \mathrm{C}$-units, the vertical reinforcements are placed in one of the $2 \mathrm{C}$ units being completely filled with mortar. This means that the addition of vertical reinforcements in beams with $2 \mathrm{C}$-units represents a considerable increase on the effective cross section of the beams. For the configuration of uniformly distributed vertical reinforcements (S-2C-S3) the hollow vertical cells are reinforced and completely filled with mortar resulting in much higher shear strength. This means that part of the increase on the shear strength is due to the increase on the effective cross section.

Besides, it should be stressed that the shear capacity of masonry beams depends on the position and distribution of vertical reinforcements (stirrups). In specimens built with 3C-units the first two reinforcement ratios increased the shear capacity. However, specimen S-3C-S3 exhibited a reduction of maximum load. This behaviour appears to be related to an increase on the compressive stresses at the struts and thus to the premature crushing of the units in the neighbourhood of the supports. On the other hand, the lower value of the shear strength obtained in specimen S-2C-S2 is attributed to the inadequate positioning of the vertical reinforcements out of the diagonal cracking band, 
leading to its minor contribution to the shear strength. However, this behaviour was not observed in specimen S-2C-S3 because it was fully filled with mortar, increasing the shear strength in region between the load application and supports.

\section{Conclusions and final remarks}

An extensive experimental program aiming at assessing the mechanical behaviour of masonry beams reinforced with truss type bars positioned at the bed joints and at the vertical cores of the units was carried out. Two load configurations were adopted in the tests, namely four and three point loads, in order to obtain predominant flexure and shear behavior. Geometry of the units and horizontal and vertical reinforcement ratios and distribution along the height and the length of the beams were the main variables analyzed in the experimental study.

Results point out that bed joint reinforcement improves the flexure behaviour of masonry beams by increasing the capacity of these elements of resist tensile stresses. It improves also the deformation capacity and enhances a better distribution of cracks leading to the delay the opening of diagonal cracking. Shear strength was also increased by the presence of horizontal reinforcement since they promote the connection of both edges of the shear crack allowing the stress transfer between them. Besides, horizontal reinforcement also contributed to shear strength and ductility through the dowel action resisting mechanism.

Vertical reinforcements increased the shear strength of the masonry beams. However, it was observed that more than the reinforcement ratio, the location and distribution of vertical reinforcements take a central role on the shear behaviour of masonry. The distribution of the vertical reinforcements must cross the diagonal 
cracking so that their positive contribution is effective for the the shear strength. The correct localization of the vertical reinforcements avoids the localization of the diagonal cracking and improves the cracking distribution.

The geometry of the units appear to influence the shear and flexural behavior of masonry beam as the compressive behavior in the direction parallel to bed joints is dependent on the masonry bond as masonry with $3 \mathrm{C}$-units is a dry stack masonry and with $2 \mathrm{C}$-units, which presents filled vertical joints. The masonry bond is also important in the shear strength of masonry as a composite material and consequetely isa alos important in the shear strength of masonry beams. The increase on the effective cross section by mortar filling of the hollow cell concrete units leads to the significant improvement on the shear strength of the masonry beams. This behaviour is mainly associated to the significant increase on the compressive and shear strength of masonry.

\section{Acknowledgements}

This work was partly supported by contract DISWALL - "Development of innovative systems for reinforced masonry walls" - COOP-CT-2005-018120 from the European Commission. The first author was supported by the Programme Alßan, the European Union Programme of High Level Scholarships for Latin America, Scholarship $\mathrm{n}^{\mathrm{o}} \mathrm{E} 06 \mathrm{D} 100148 \mathrm{BR}$. 


\section{References}

Adell, J. M.; Garcia-Santos, A.; Lauret, B.; López, C.; Martín, H.; Peña, J.; Pol, M.; Timperman, P.; Veja, S. (2008). "6m span lintels tests on a new wall PI-brackets type", Proceedings of 14th International Brick/block Masonry Conference, Austin, Australia, $10 \mathrm{pp}$.

ASTM E519-02: Standard Test Method for Diagonal Tension (Shear) in Masonry Assemblages, 2000.

Chen, Y.; Ashour, A. F.; Garrity, S. W. (2008). "Moment/thrust interaction diagrams for reinforced masonry sections", Contruction and Building Materials, 22(5), 763-770.

Drysdale, R.G., Hamid, A.A., Baker, L.R. (1999). “Masonry structures: behaviour and design", The Masonry Society, Boulder, Colorado, USA.

EUROPEAN STANDARD. EN 772-1, Methods of tests for masonry units - Part1:

Determination of compressive strength. 2000.

EUROPEAN STANDARD. EN 846-9, Methods of tests for ancillary components for masonry - Part 9: Determination of flexural resistance and shear resistance of lintels, 2000.

EUROPEAN STANDARD. EN 1015-3, Methods of test for mortar for masonry: Part 3:

Determination of consistence of fresh mortar (by flow table), 1999.

EUROPEAN STANDARD. EN 1015-11, Methods of tests for mortar for masonry -

Part 11: Determination of flexure and compressive strength of hardened mortar. 1999.

EUROPEAN STANDARD. EN 1052-1, Methods of test for masonry - Part1:

Determination of compressive strength. 1999. 
EUROPEAN STANDARD. EN 1996-1-1, Eurocode 6: Design of masonry structures, 2005.

Haach, V.G.; Vasconcelos, G.; Lourenço, P. B.; Mohamad, G. (2007). "Study of a mortar to use as infill and embedding", Proceedings of 10th North American Masonry Conference, St. Louis, Missouri, USA, 530-541.

Haach, V.G.; Vasconcelos, G.; Lourenço, P. B.; Mohamad, G. (2008). “Influence Of The Mortar On The Compressive Behavior Of Concrete Masonry Prisms", Proceedings of 7th National Congress in Experimental Mechanics, Vila Real, Portugal. Haach, V.G., Vasconcelos, G., Lourenço, P.B., Influence of the geometry of units and filling of vertical joints in the compressive and tensile strength of masonry, Special Issue of Materials Science Forum, Vols 636, 1321-1328, 2010.

Haach, V.G., Vasconcelos, G., Lourenço, P.B., Assessment of the flexural behaviour of concrete block masonry beams, Special Issue of Materials Science Forum, Vols 636, 1313-1320, 2010.

Haach, V.G., Vasconcelos, G., Lourenço, P.B., Experimental analysis of reinforced concrete block masonry walls subjected to in-plane cyclic loads, ASCE, Journal of Structural Engineering, 136(4), 452-462, 2010.

Hendry, A.W. (1998). “Structural Masonry”, MacMillan Press LTDA, London, UK. Jang, J. J.; Hart, G. C. (1995). “Analysis of concrete masonry beams”, Journal of structural engineering, 121(11), 1598-1602.

Khalaf, F. M., Glanville, J. I., El Shahawi, M. (1983). "A study of flexure in reinforced masonry beams", Concrete International, 5(6), 46-53. 
Limón, T. G.; Hortelano, A. M., Fernández, B. M. (2000). "Vertical flexural behaviour of bed joint reinforced brick masonry", Proceeding of 12th International Brick and Block Masonry Conference, Madrid, Spain, 10pp.

Taly, N. (2001). "Design of reinforced masonry structures", McGraw-Hill, New York, USA. 


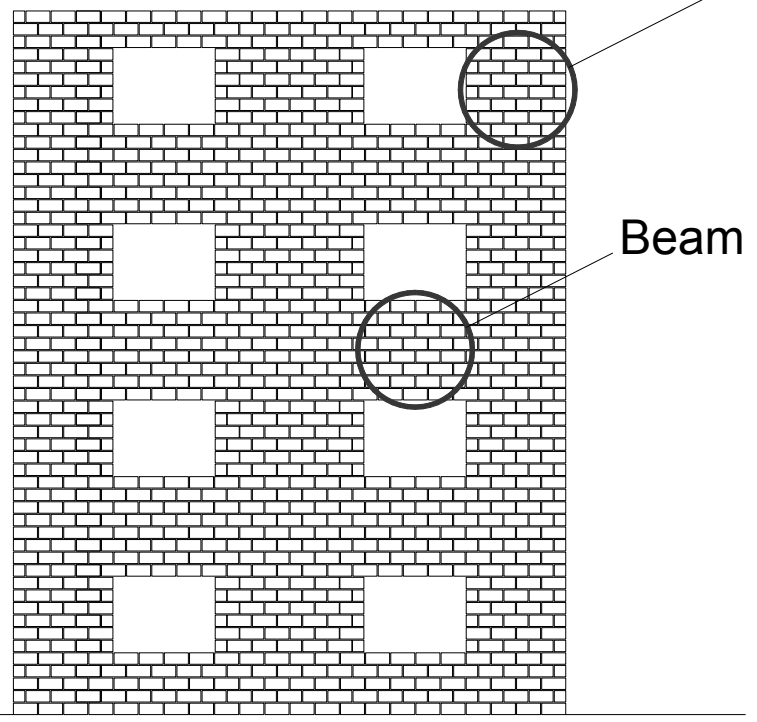

Shear wall

Fig. 1 - Localization of masonry beams.
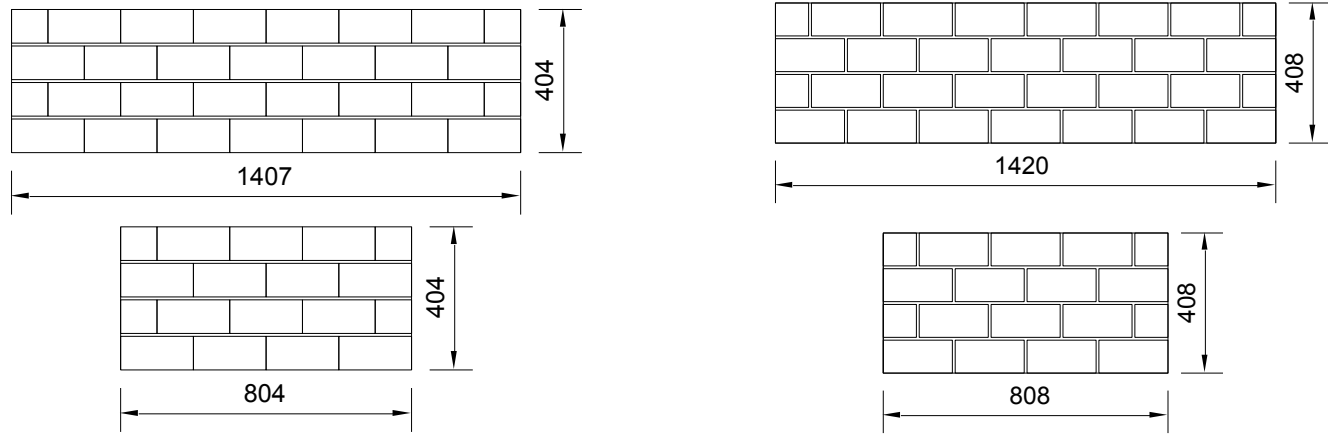

(b)

Fig. 2 - Geometry of masonry beams: (a) masonry beams built with 3C-units and (b)

masonry beams built with $2 \mathrm{C}$-units (dimensions in $\mathrm{mm}$ )

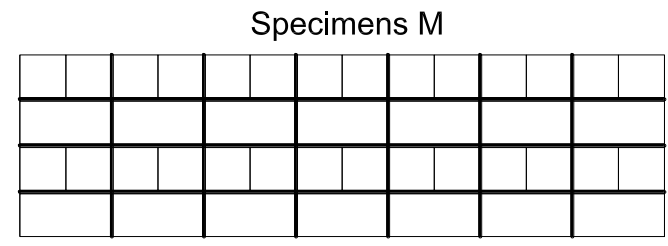

Other specimens

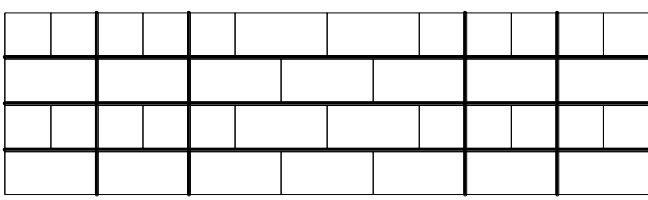

(a)

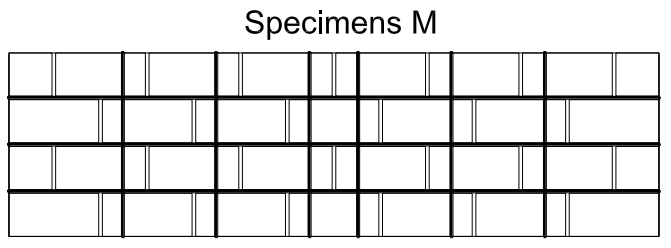

Other specimens

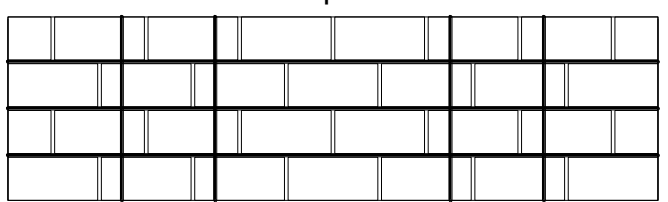

(b)

Fig. 3 - Location of the vertical reinforcements in four point load configuration: (a)

masonry beams built with 3C-units and (b) masonry beams built with $2 \mathrm{C}$-units 
S-2C-S1

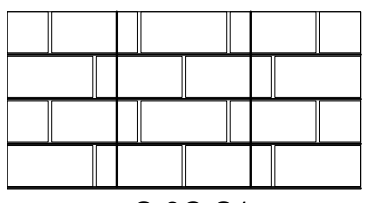

S-3C-S1

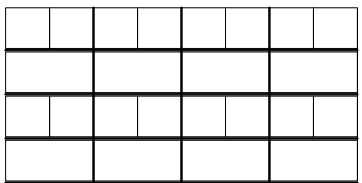

S-2C-S2

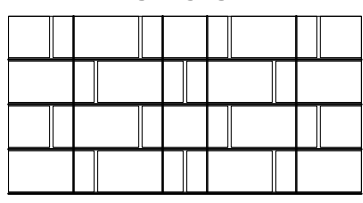

S-3C-S2

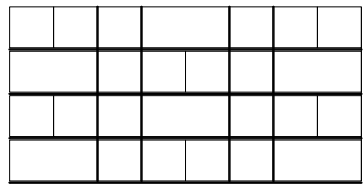

S-2C-S3

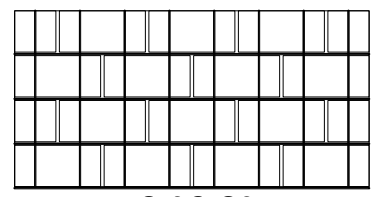

S-3C-S3

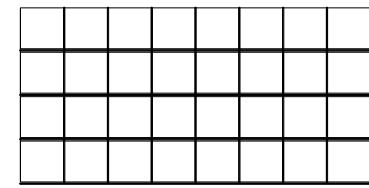

Fig. 4 - Location of vertical reinforcements in masonry beams for three point load tests

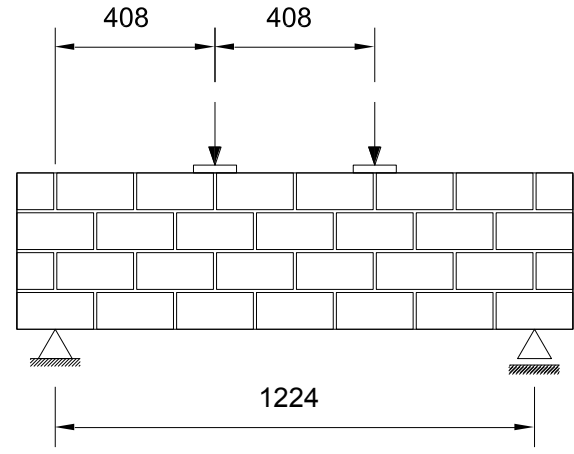

(a)

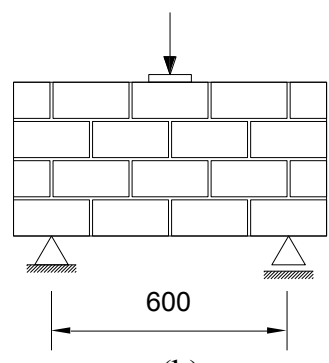

(b)

Fig. 5 - Test setup of masonry beams: (a) four point load test and (b) three point load test (dimensions in $\mathrm{mm}$ ).

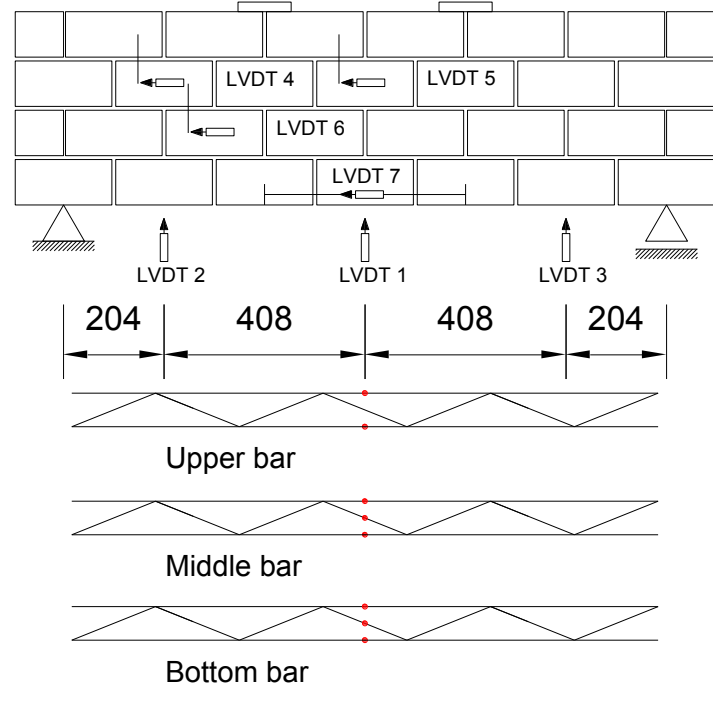

(a)

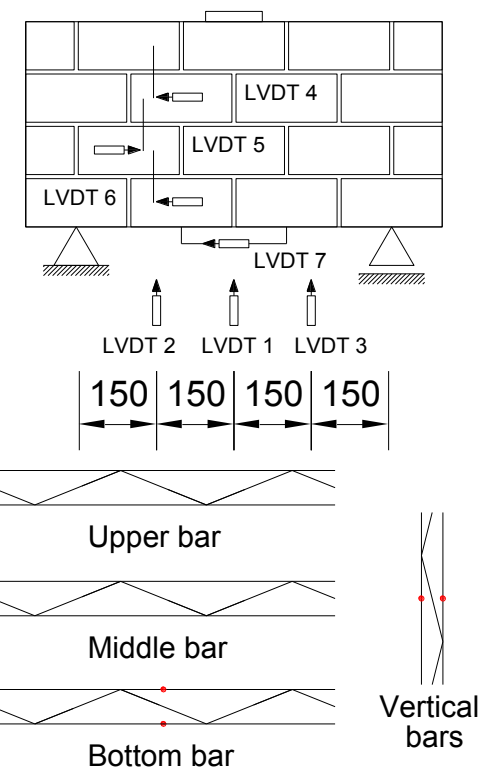

(b)

Fig. 6 - Instrumentation of the masonry beams: (a) four point load tests and (b) three point load tests (dimensions in $\mathrm{mm}$ ). 
F-3C-UM

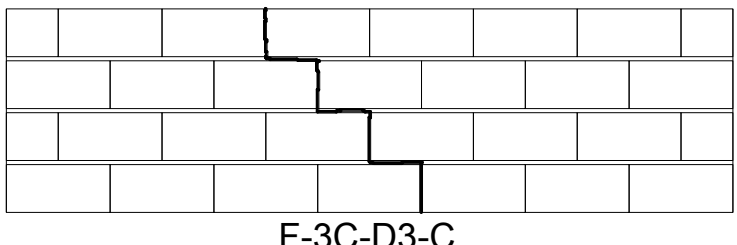

F-3C-D3-C

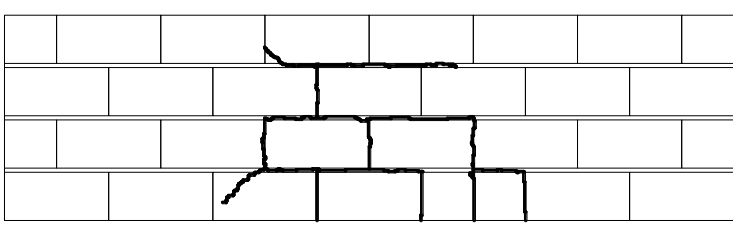

F-3C-D3-D

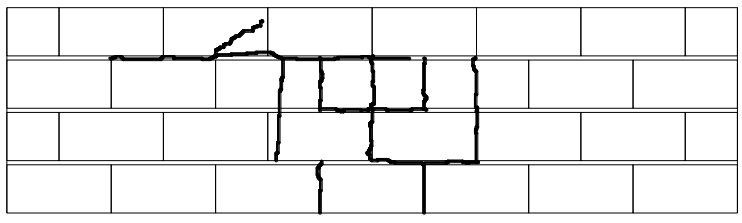

F-3C-D3-D-M

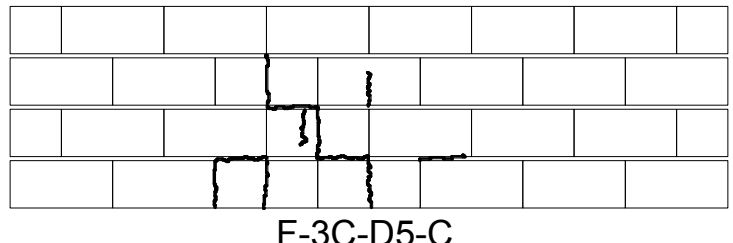

F-3C-D5-C

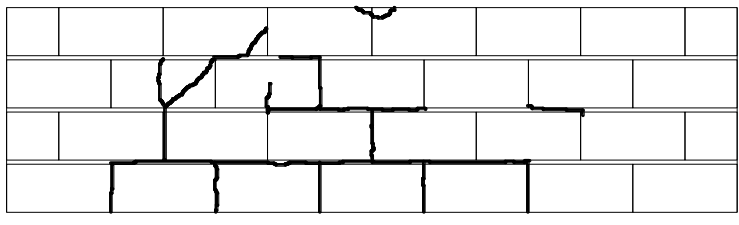

F-3C-D5-D

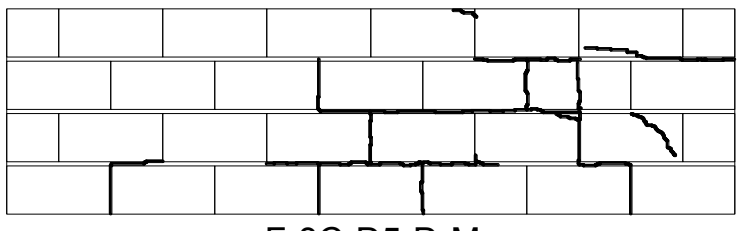

F-3C-D5-D-M

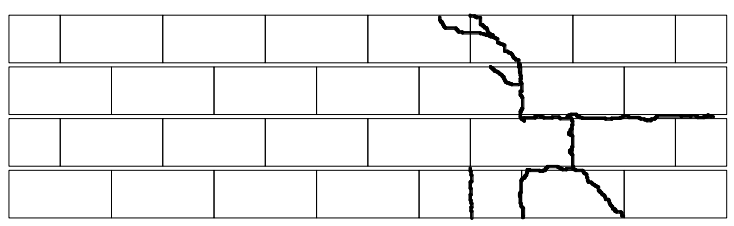

F-2C-UM

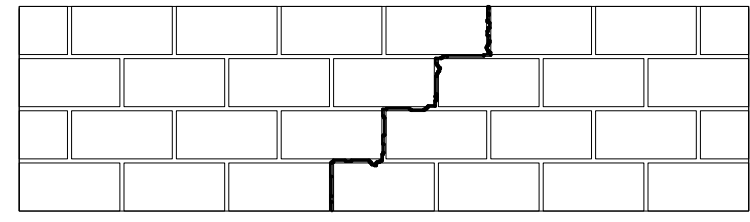

F-2C-D3-C

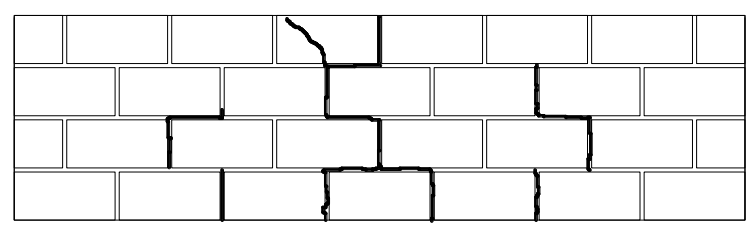

F-2C-D3-D

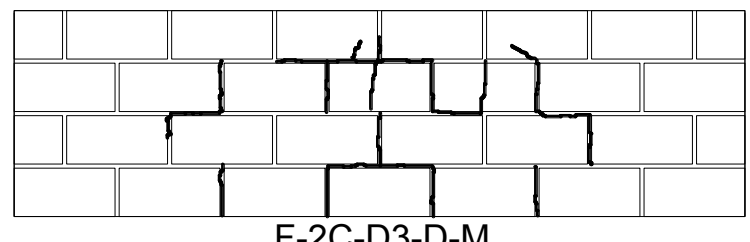

F-2C-D3-D-M
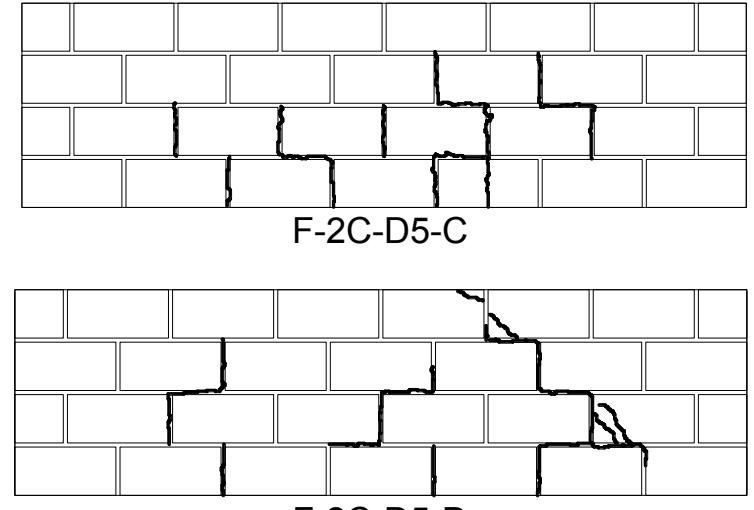

F-2C-D5-D
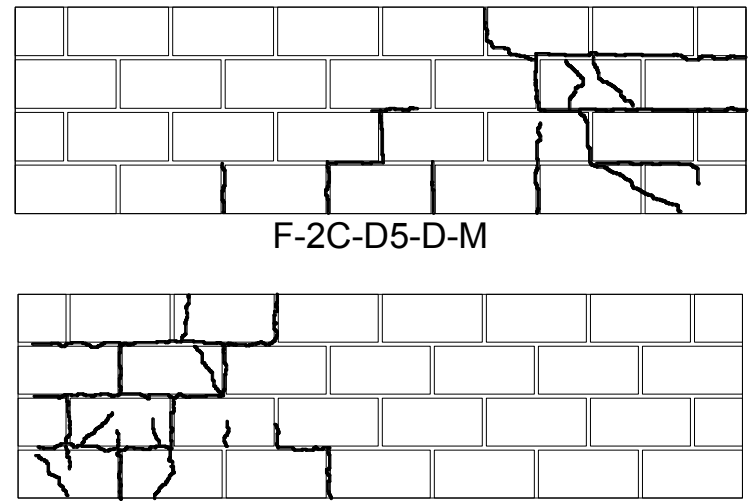

Fig. 7 - Cracking patterns of masonry beams in four point load tests. 


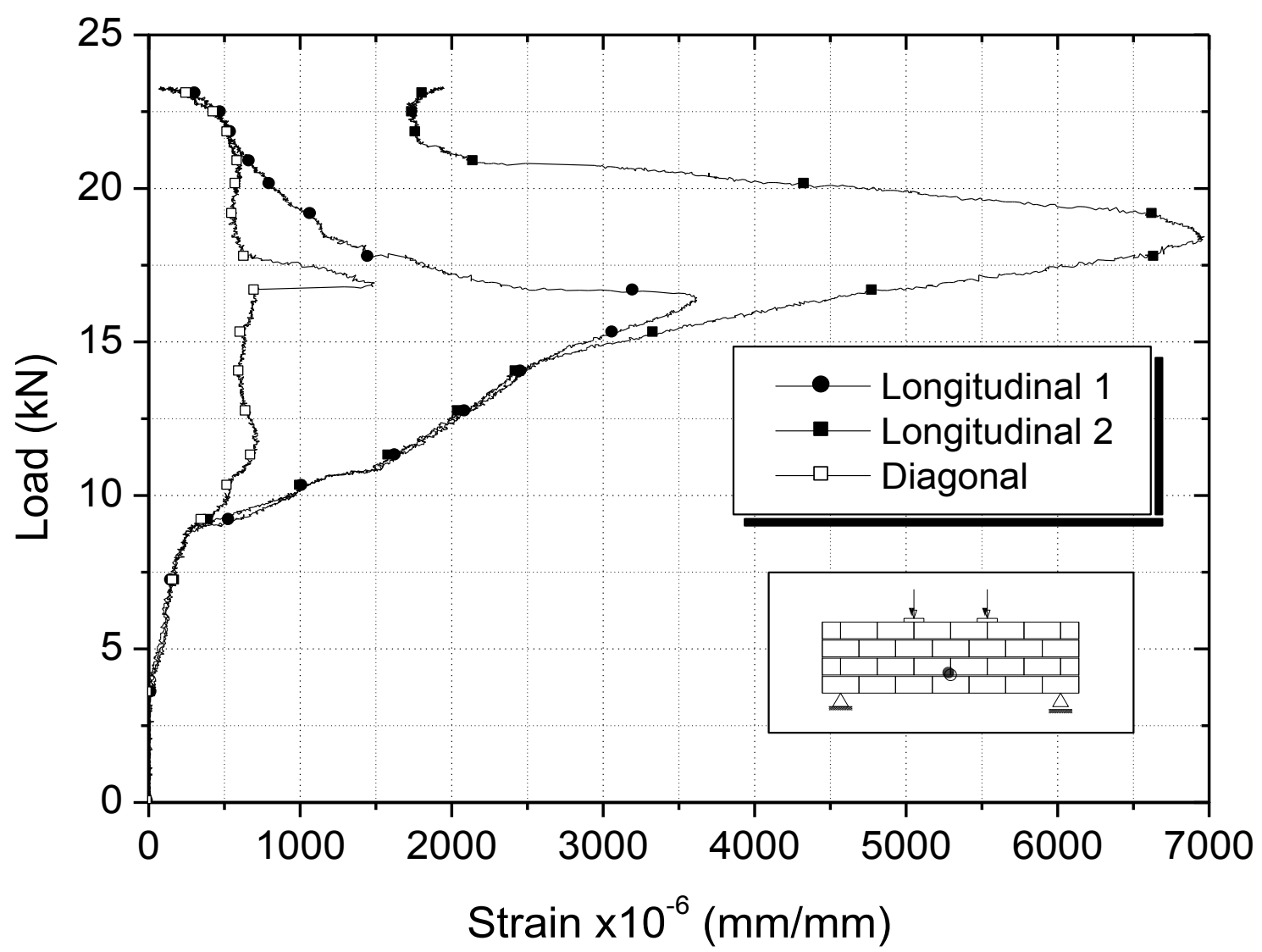

Fig. 8 - Strains in horizontal reinforcement of specimen F-3C-D3-C. 


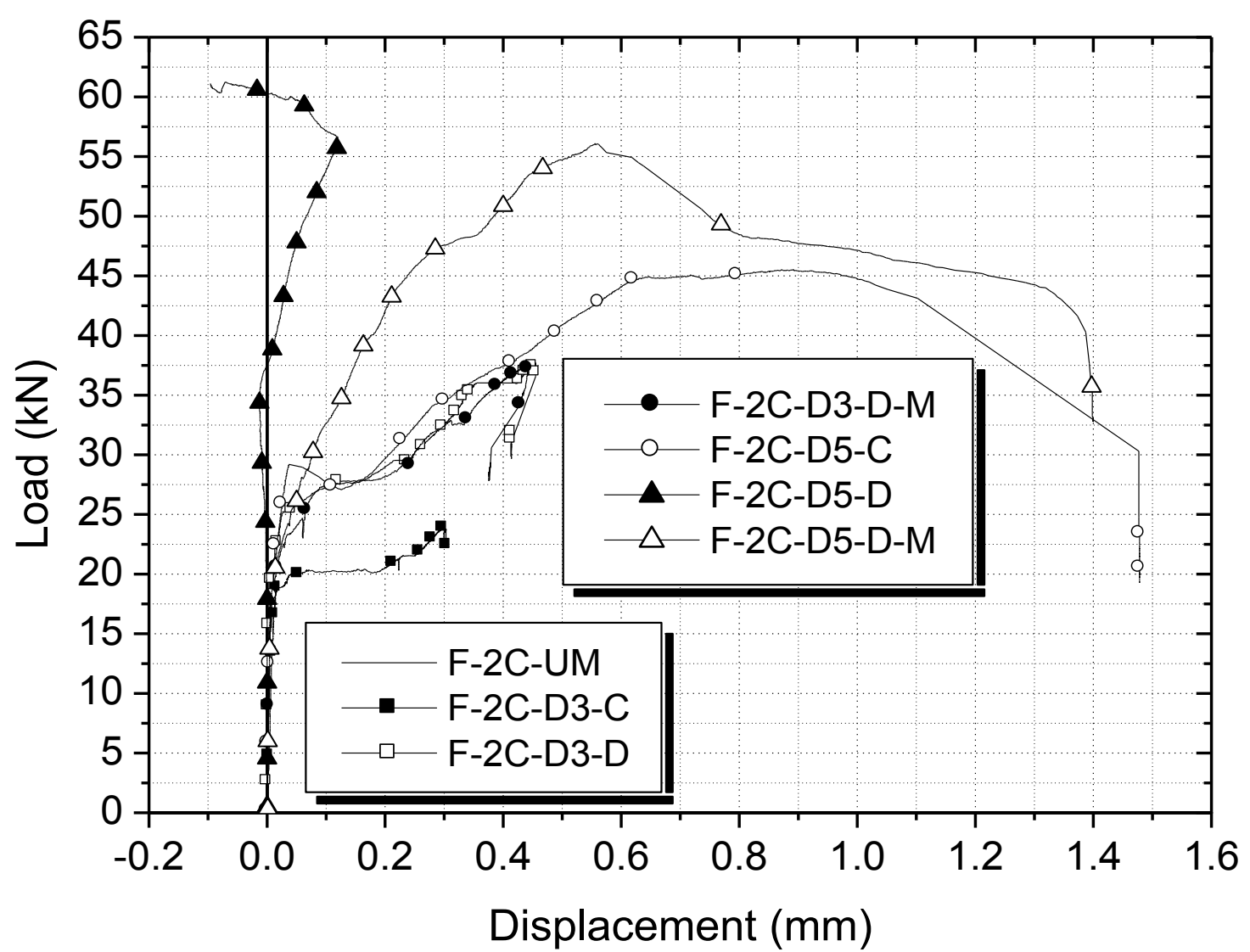

Fig. 9 - Results of the LVDT 6 of beams measuring the opening of diagonal cracks for specimens built with 2C-units. 


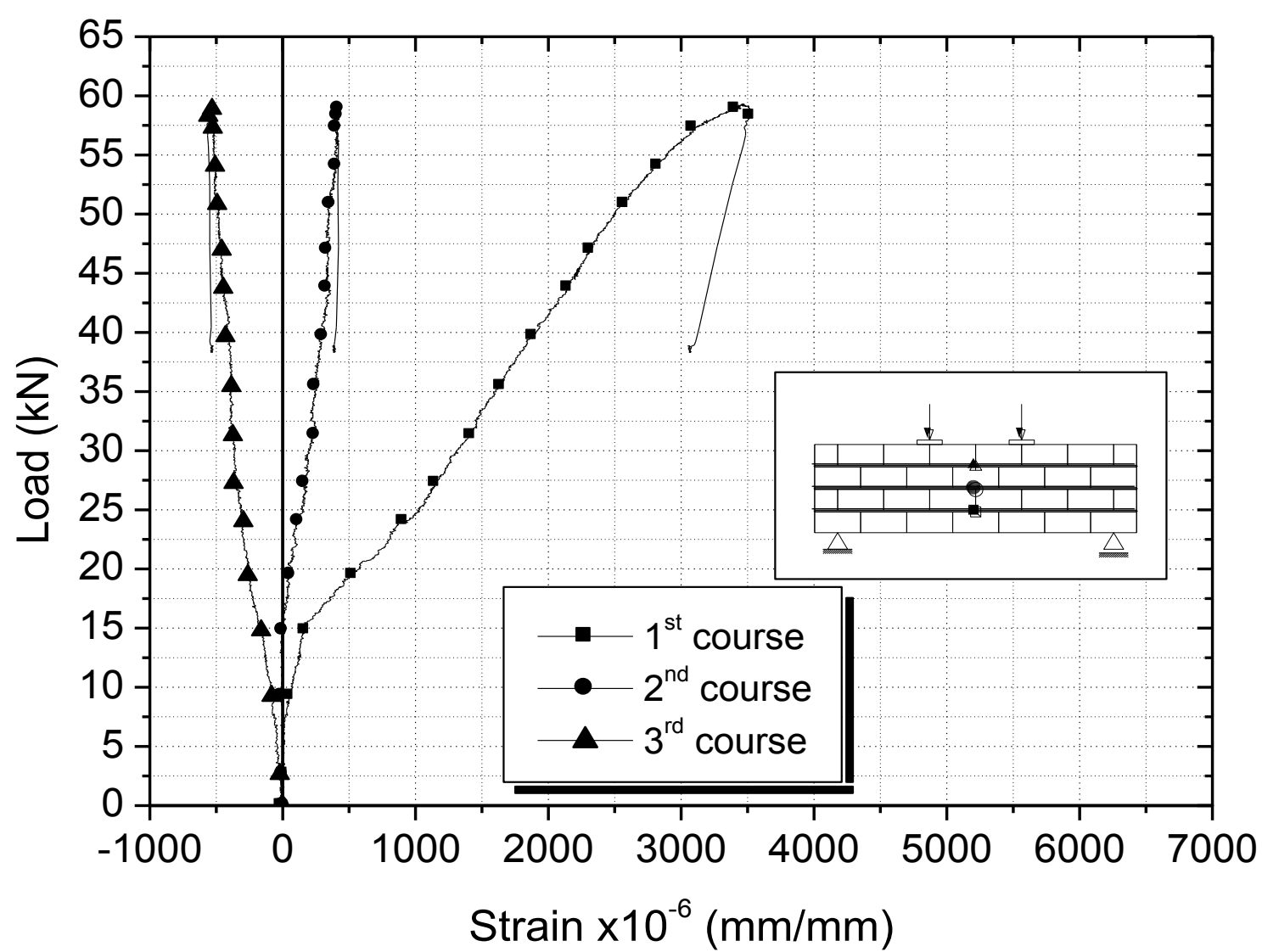

Fig. 10 - Strains in horizontal reinforcements of specimen F-3C-D5-D-M. 


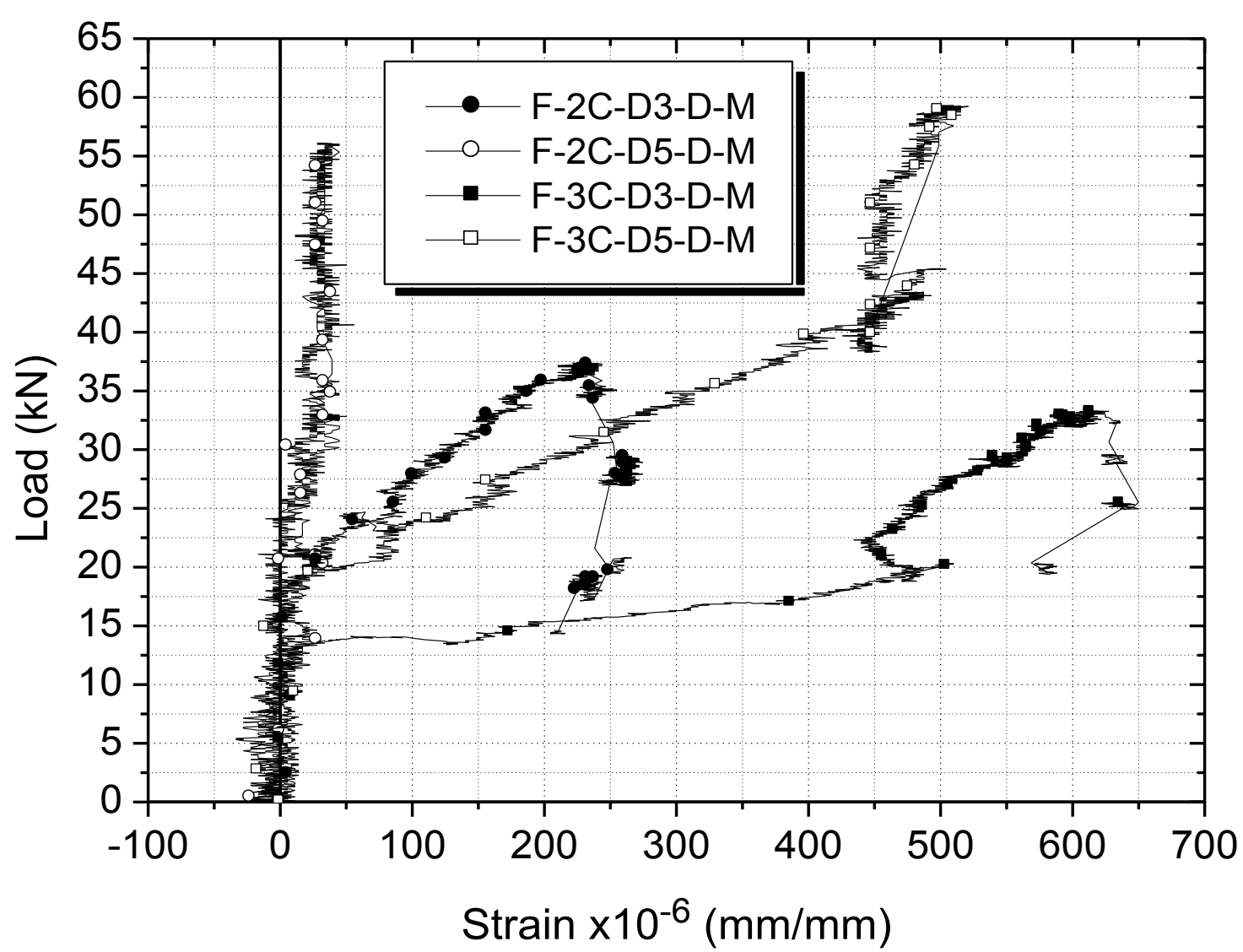

Fig. 11 - Strains measured at the central vertical reinforcements in four point load tests.

S-3C-UM

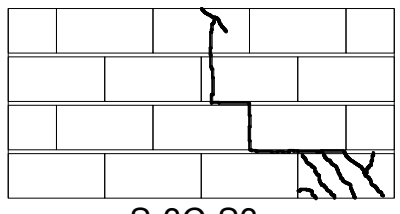

S-3C-S3

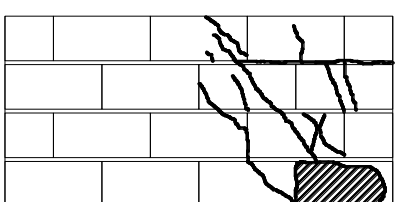

S-2C-S2

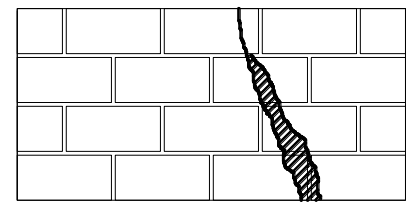

S-3C-S1
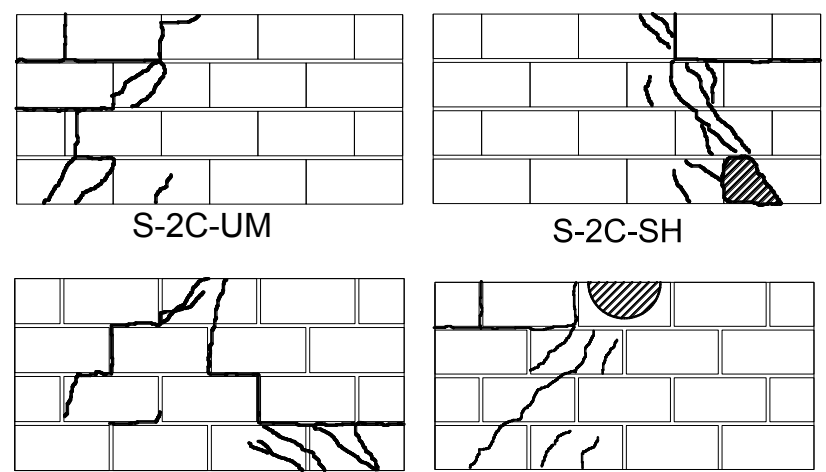

$\mathrm{S}-2 \mathrm{C}-\mathrm{SH}$

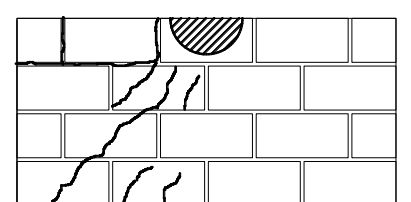

S-2C-S3

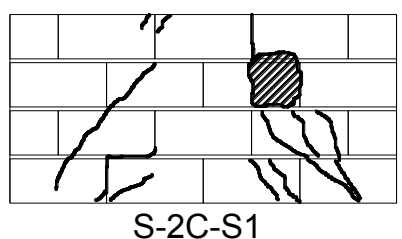

S-2C-S1
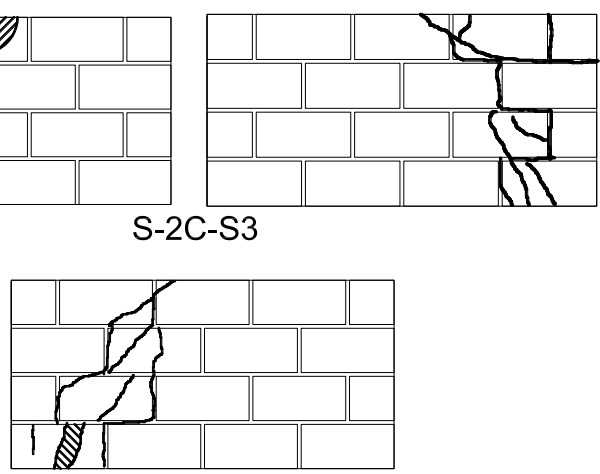

Fig. 12 - Cracking patterns in three point load tests. 


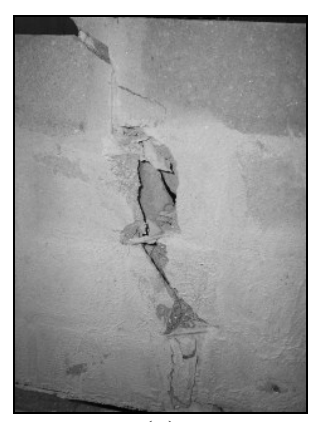

(a)

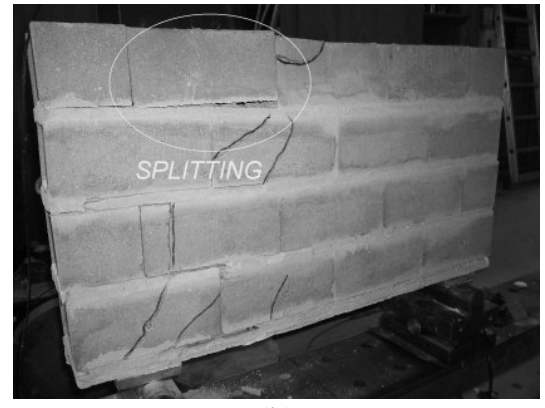

(b)

Fig. 13 - Damage states on the masonry beams: (a) thick localized shear crack and dowel action effect of the horizontal reinforcements through diagonal crack (S-2C-S2) and (b) splitting of blocks at the third course (S-3C-SH). 


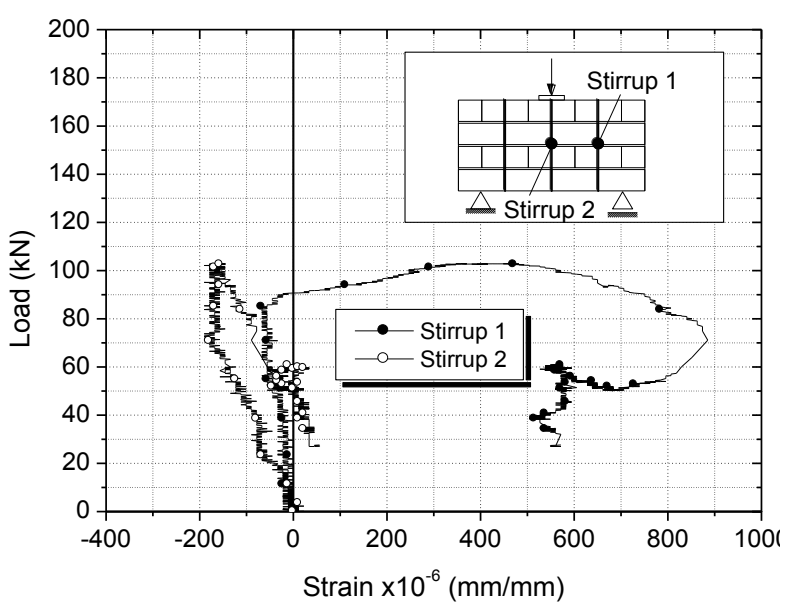

(a)

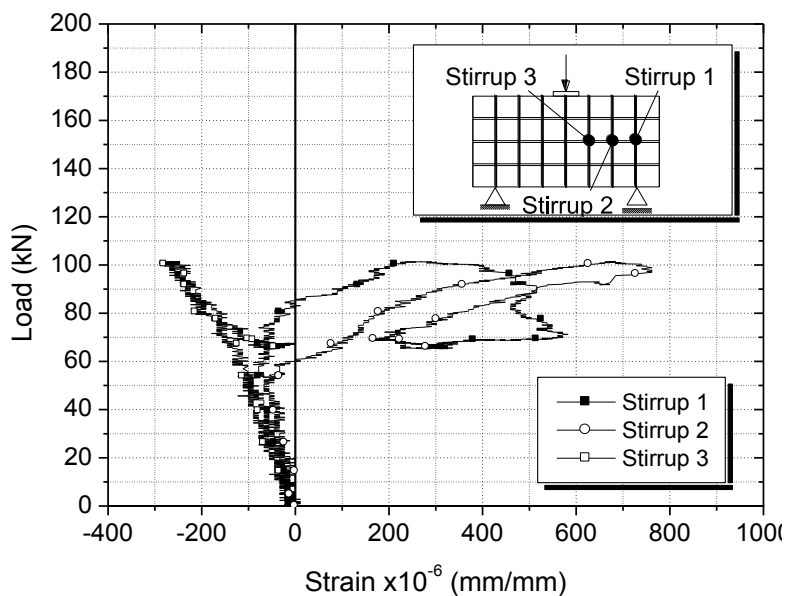

(c)

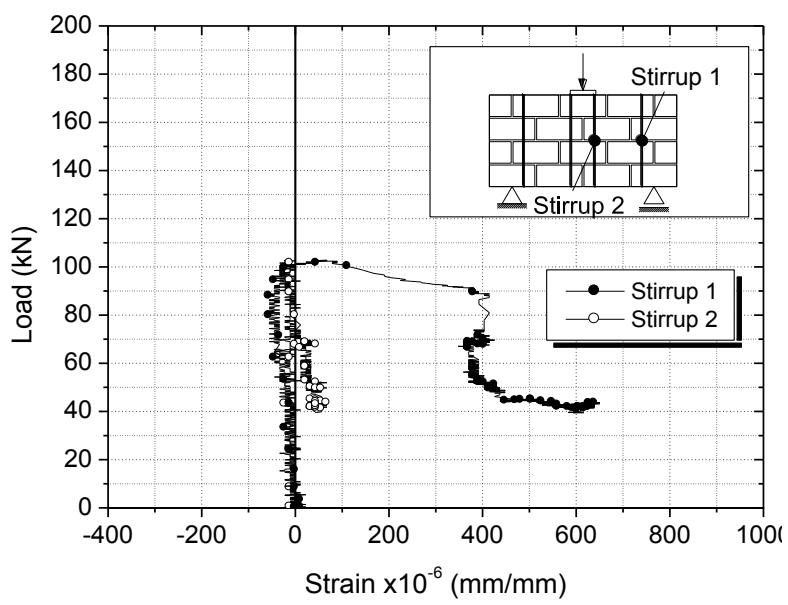

(e)

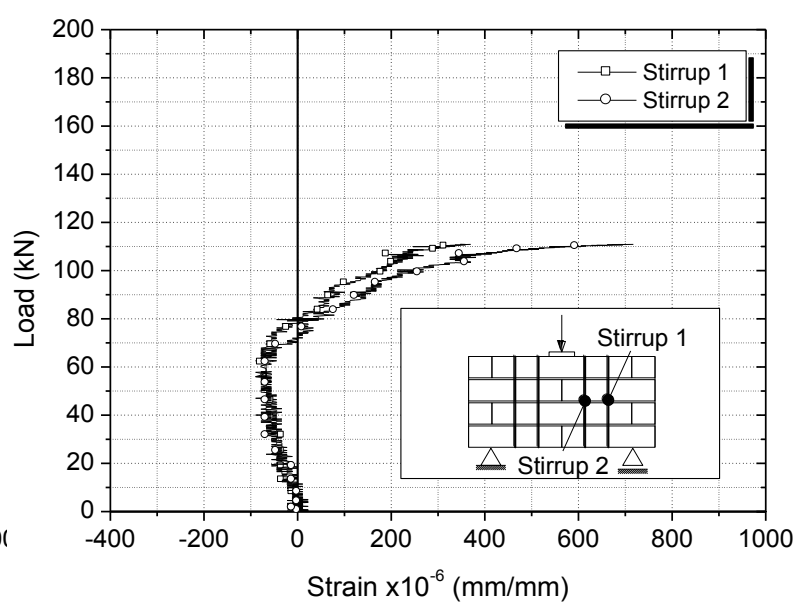

(b)

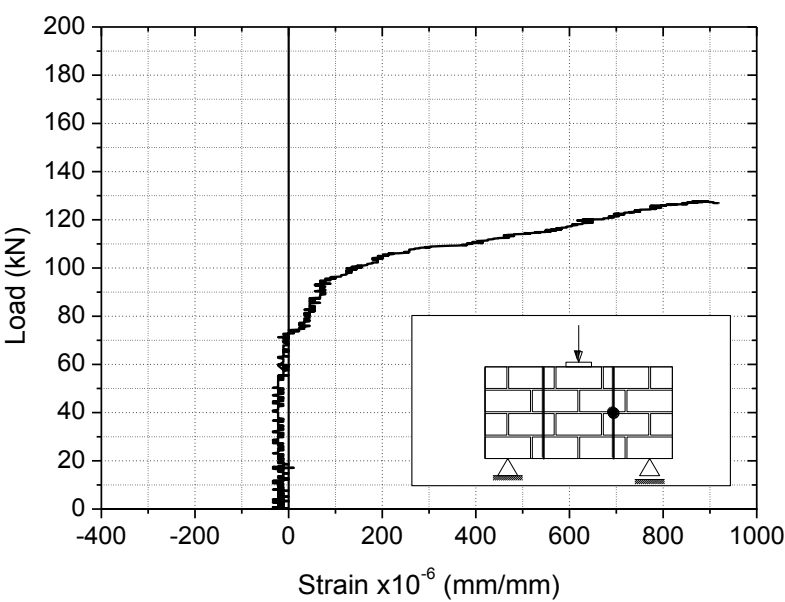

(d)

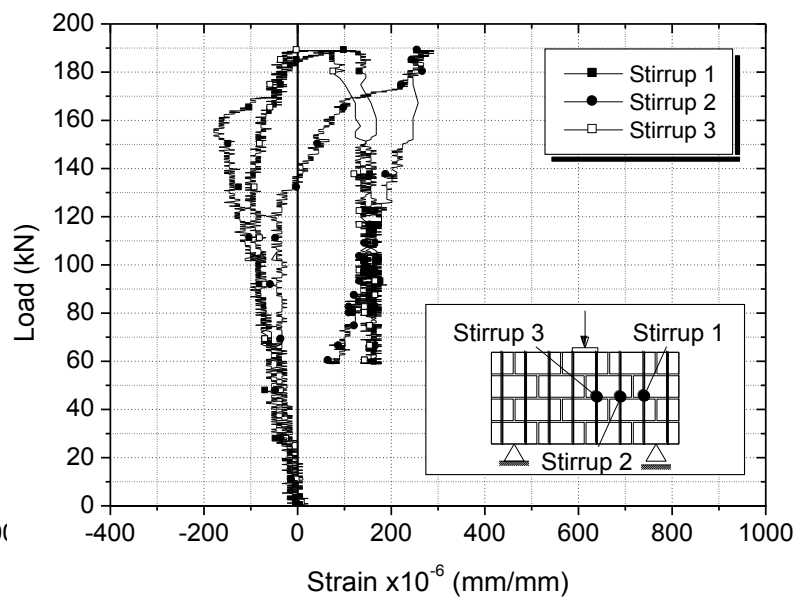

(f)

Fig. 14 - Strains in vertical reinforcements of the masonry beams: (a) S-3C-S1, (b) S-

3C-S2, (c) S-3C-S3, (d) S-2C-S1, (e) S-2C-S2 and (f) S-2C-S3. 


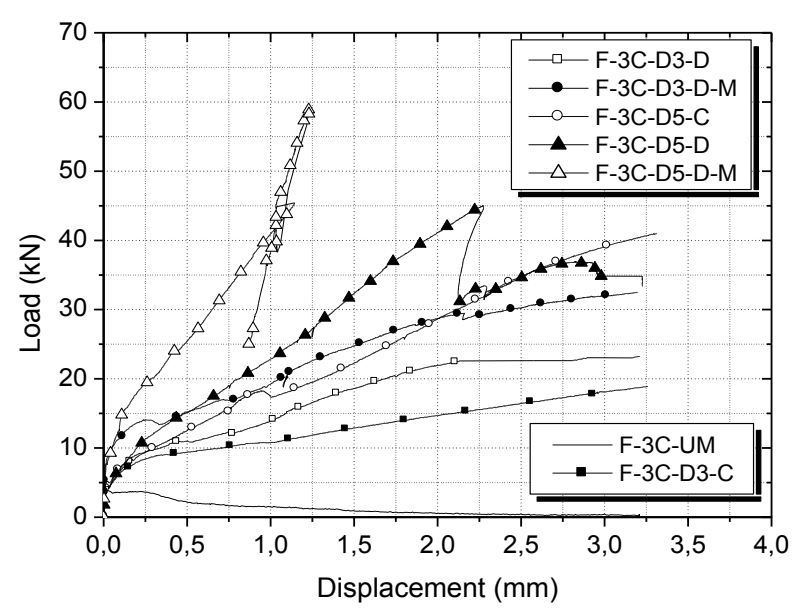

(a)

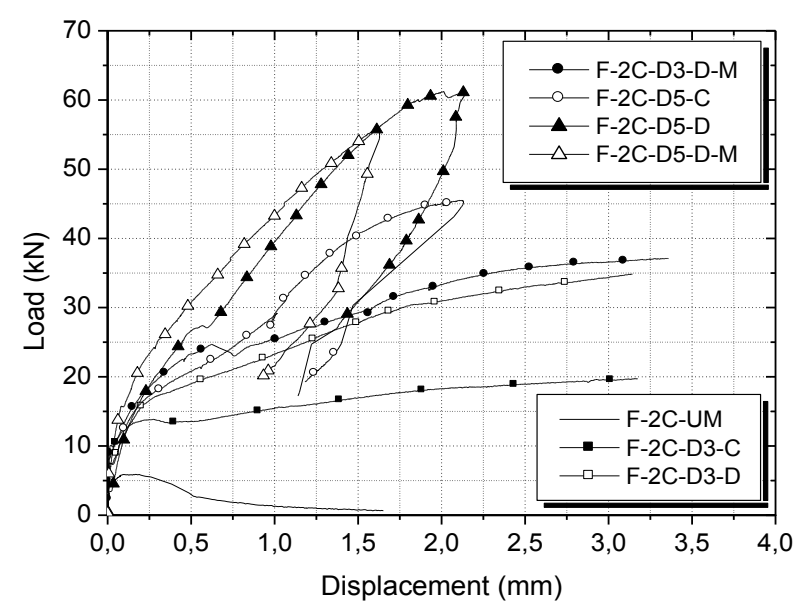

(b)

Fig. 15 - Force-displacement diagrams of masonry beams tested under four point loading configuration: (a) 3C-units and (b) 2C-units.

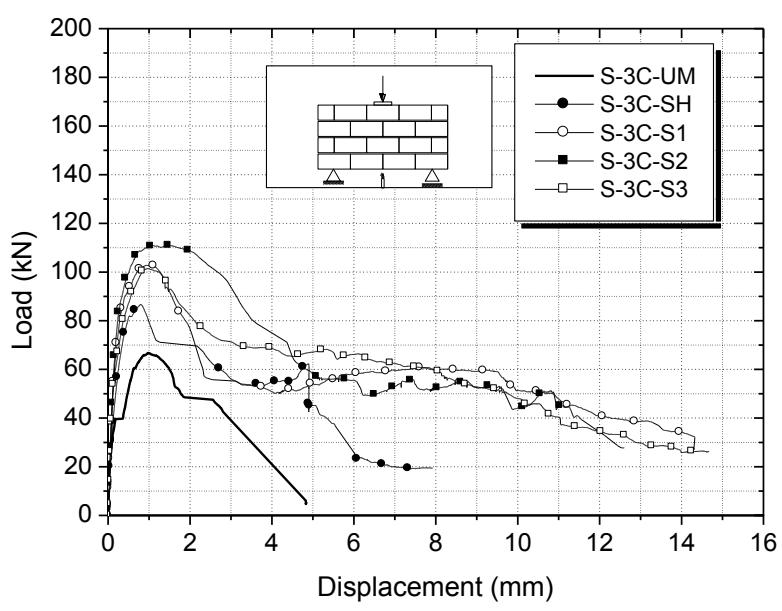

(a)

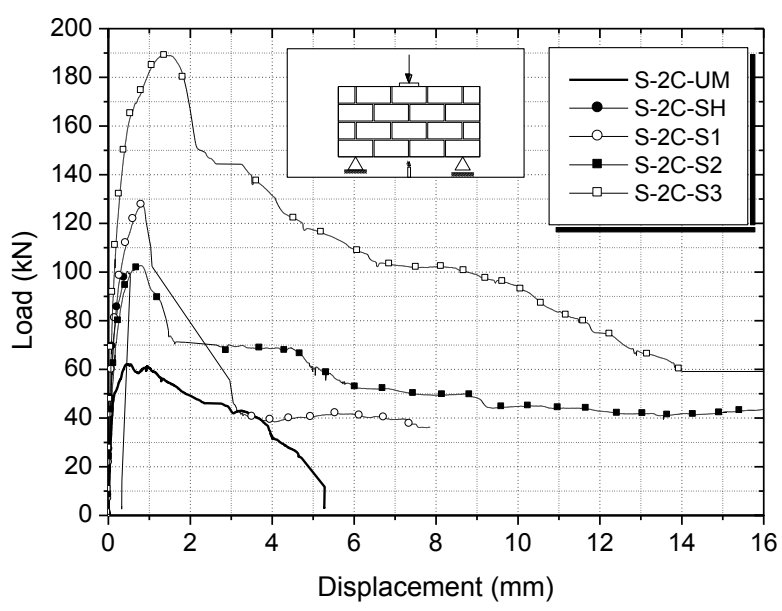

(b)

Fig. 16 - Force-displacement diagrams of masonry beams tested under three load point configuration: (a) 3C-units and (b) 2C-units. 
Table 1 - Experimental details of masonry beams.

\begin{tabular}{cccccc}
\hline Beam & $\begin{array}{c}\boldsymbol{\sigma}_{\mathrm{h}} \\
(\mathrm{mm})\end{array}$ & $\begin{array}{c}\rho_{\mathrm{h}} \\
(\%)\end{array}$ & $\begin{array}{c}\boldsymbol{\emptyset}_{\mathrm{v}} \\
(\mathrm{mm})\end{array}$ & $\begin{array}{c}\rho_{\mathrm{v}} \\
(\%)\end{array}$ & $\begin{array}{c}\text { Dimensions } \\
(\mathrm{mm})\end{array}$ \\
\hline F-3C-UM & - & - & 5 & 0.112 & $1407 \times 404 \times 100$ \\
\hline F-3C-D5-C & 5 & 0.097 & 5 & 0.112 & $1407 \times 404 \times 100$ \\
\hline F-3C-D5-D & 5 & 0.292 & 5 & 0.112 & $1407 \times 404 \times 100$ \\
\hline F-3C-D5-D-M & 5 & 0.292 & 5 & 0.167 & $1407 \times 404 \times 100$ \\
\hline F-3C-D3-C & 3 & 0.035 & 5 & 0.112 & $1407 \times 404 \times 100$ \\
\hline F-3C-D3-D & 3 & 0.105 & 5 & 0.112 & $1407 \times 404 \times 100$ \\
\hline F-3C-D3-D-M & 3 & 0.105 & 5 & 0.167 & $1407 \times 404 \times 100$ \\
\hline F-2C-UM & - & - & 5 & 0.118 & $1420 \times 408 \times 94$ \\
\hline F-2C-D5-C & 5 & 0.102 & 5 & 0.118 & $1420 \times 408 \times 94$ \\
\hline F-2C-D5-D & 5 & 0.307 & 5 & 0.118 & $1420 \times 408 \times 94$ \\
\hline F-2C-D5-D-M & 5 & 0.307 & 5 & 0.177 & $1420 \times 408 \times 94$ \\
\hline F-2C-D3-C & 3 & 0.037 & 5 & 0.118 & $1420 \times 408 \times 94$ \\
\hline F-2C-D3-D & 3 & 0.111 & 5 & 0.118 & $1420 \times 408 \times 94$ \\
\hline F-2C-D3-D-M & 3 & 0.111 & 5 & 0.177 & $1420 \times 408 \times 94$ \\
\hline S-3C-UM & - & 0.292 & - & - & $804 \times 404 \times 100$ \\
\hline S-3C-SH & 5 & 0.292 & 4 & 0.094 & $804 \times 404 \times 100$ \\
\hline S-3C-S1 & 5 & 0.292 & 4 & 0.125 & $804 \times 404 \times 100$ \\
\hline S-3C-S2 & 5 & 0.292 & 4 & 0.219 & $804 \times 404 \times 100$ \\
\hline S-3C-S3 & 5 & - & - & - & $804 \times 404 \times 100$ \\
\hline S-2C-UM & - & 0.307 & - & - & $808 \times 408 \times 94$ \\
\hline S-2C-SH & 5 & 0.307 & 4 & 0.066 & $808 \times 408 \times 94$ \\
\hline S-2C-S1 & 5 & 0.307 & 4 & 0.132 & $808 \times 408 \times 94$ \\
\hline S-2C-S2 & 5 & 0.307 & 4 & 0.199 & $808 \times 408 \times 94$ \\
\hline S-2C-S3 & 5 & 0.292 & - & - & $808 \times 408 \times 94$ \\
\hline & & & & & \\
\hline
\end{tabular}


Table 2 - Cracking and maximum loads in four point load tests.

\begin{tabular}{cccccc}
\hline Beam & $\begin{array}{c}\text { Flexural } \\
\text { strength } \\
\text { of mortar } \\
(\mathrm{MPa})\end{array}$ & $\begin{array}{c}\text { Compressive } \\
\text { Strength of } \\
\text { mortar } \\
(\mathrm{MPa})\end{array}$ & $\begin{array}{c}\text { Flexural } \\
\text { Cracking } \\
\text { Load } \\
(\mathbf{k N})\end{array}$ & $\begin{array}{c}\text { Diagonal } \\
\text { Cracking } \\
\text { Load } \\
(\mathbf{k N})\end{array}$ & $\begin{array}{c}\text { Maximum } \\
\text { Load } \\
(\mathrm{kN})\end{array}$ \\
\hline F-3C-UM & 1.85 & 6.79 & 4.05 & - & 4.05 \\
\hline F-3C-D3-C & 1.92 & 7.32 & 3.84 & - & 23.32 \\
\hline F-3C-D3-D & 2.15 & 8.09 & 4.43 & - & 33.19 \\
\hline F-3C-D3-D-M & 2.18 & 8.54 & 8.69 & - & 33.30 \\
\hline F-3C-D5-C & 1.85 & 6.79 & 4.80 & 15.70 & 44.90 \\
\hline F-3C-D5-D & 2.15 & 8.09 & 5.15 & 23.05 & 45.04 \\
\hline F-3C-D5-D-M & 2.15 & 8.09 & 7.60 & 18.18 & 59.31 \\
\hline F-2C-UM & 1.65 & 5.66 & 5.10 & - & 5.90 \\
\hline F-2C-D3-C & 1.65 & 5.66 & 8.93 & 18.87 & 24.09 \\
\hline F-2C-D3-D & 1.89 & 7.15 & 7.52 & 24.41 & 37.73 \\
\hline F-2C-D3-D-M & 1.92 & 7.32 & 10.06 & 21.88 & 37.38 \\
\hline F-2C-D5-C & 1.89 & 7.15 & 7.43 & 24.78 & 45.54 \\
\hline F-2C-D5-D & 1.92 & 7.32 & 3.48 & 41.72 & 61.24 \\
\hline F-2C-D5-D-M & 2.18 & 8.54 & 7.82 & 22.29 & 56.10 \\
\hline
\end{tabular}

Table 3 - Cracking and maximum loads in three point load tests.

\begin{tabular}{ccccc}
\hline Beam & $\begin{array}{c}\text { Flexural } \\
\text { strength } \\
\text { of mortar } \\
(\mathrm{MPa})\end{array}$ & $\begin{array}{c}\text { Compressive } \\
\text { Strength of } \\
\text { mortar } \\
(\mathrm{MPa})\end{array}$ & $\begin{array}{c}\text { Diagonal } \\
\text { Cracking } \\
\text { Load } \\
(\mathrm{kN})\end{array}$ & $\begin{array}{c}\text { Maximum } \\
\text { Load } \\
(\mathrm{kN})\end{array}$ \\
\hline S-3C-UM & 1.98 & 7.56 & 39.80 & 66.80 \\
\hline S-3C-SH & 1.98 & 7.56 & 83.20 & 86.68 \\
\hline S-3C-S1 & 1.75 & 6.39 & 86.80 & 102.91 \\
\hline S-3C-S2 & 1.98 & 7.56 & 80.00 & 110.89 \\
\hline S-3C-S3 & 1.75 & 6.39 & 80.57 & 101.43 \\
\hline S-2C-UM & 1.94 & 7.18 & 49.90 & 62.11 \\
\hline S-2C-SH & 1.98 & 7.56 & 70.00 & 100.34 \\
\hline S-2C-S1 & 1.94 & 6.39 & 75.00 & 127.61 \\
\hline S-2C-S2 & 1.94 & 7.18 & 102.75 & 102.75 \\
\hline S-2C-S3 & 1.94 & 7.18 & 149.60 & 188.96 \\
\hline & & & &
\end{tabular}

